\title{
De samenwerking van de Vlaamsgezinden doorheen de geschiedenis van de Vlaamse Beweging.
}

\section{DE VROEDE}

Heden ten dage zijn Vlaamsgezinden van uiteenlopende richting werkzaam in verschillende politieke partijen en groeperingen. Daarnaast ziet men een Vlaamsnationale partij in de Vlaamse gewesten zelfstandig opereren. Aan de andere kant treft men in recente tijd ook voorbeelden aan van overleg en gezamenlijk optreden tot realisatie van een gemeenschappelijk doel, de levensbeschouwelijke tegenstellingen ten spijt. Met dat beeld voor ogen, kan men zich diverse vragen stellen. Wat was in het verleden de dominante: het gescheiden optreden naar buiten, of de gemeenschappelijke actie? Waartoe leidde de ideologische verdeeldheid in de vlaamsgezinde gelederen? Welke betekenis heeft anderdeels de samenwerking gehad en welke vorm heeft ze aangenomen? Was het een actie over de partijen heen, of binnen één eigen partij? Hoe dient de ontwikkeling uiteindeijjk te worden verklaard?

In de literatuur over de geschiedenis van de Vlaamse Beweging ${ }^{1}$ vindt men ruime informatie betreffende de gestelde problematiek. De samenwerking van de Vlaamsgezinden doorheen die geschiedenis is echter nog niet het specifieke thema geweest van wetenschappelijke publikaties. Een synthetisch overzicht ervan ontbreekt. Onderhavige bijdrage wil daartoe een poging zijn, binnen bepaalde perken. De ontwikkeling van de vlaamsgezinde actie dient in het kader van de politieke en sociale evolutie van België ruimer te worden gesitueerd dan hier het geval kan zijn. We zullen ze anderdeels niet volgen tot op heden. Vermits de verklaring van de huidige situatie vooral in de periode vóór 1914 moet worden gezocht, zullen we onze aandacht hoofdzakelijk daaraan besteden.

Waar het er in wezen om te doen is, enkele grote lijnen te trekken en de verklaring daarvan te geven, zullen we weinig in detail treden. De aangehaalde verschijnselen mogen volstaan tot globale beantwoording van de opgeworpen vragen. Indien we echter van de samenwerking der Vlaamsgezinden doorheen het verloop van de Vlaamse Beweging een vollediger beeld willen verkrijgen, samen met een meer verantwoord inzicht in de positieve aspecten en gevolgen daarvan, dan zal nog heel wat studie nodig zijn; het verschijnsel dient onder meer ook op lokaal vlak in concreto te worden onderzocht.

1. Zie achteraan de literatuuropgave. 
Gedurende de jaren 1830 ontplooide zich in de Vlaamse gewesten een literaire en publicistische activiteit die levenskrachtiger bleek dan tevoren. Stimulerend werkte daarbij de zucht tot behoud van het volkseigene, zoals zich dat in de taal manifesteerde. De Vlaamse Beweging ontwikkelde zich toen in een periode van unionisme; in de algemene landspolitiek kwamen ideologische geschilpunten niet naar voren. Een politieke tegenstelling vertoonde de Vlaamse Beweging in haar schoot nog niet. Ze was zelf nog geen politieke beweging. Onder haar aanhangers telde men liberalen, in de toenmalige betekenis, en katholieke traditionalisten. Het meest opvallend onderscheid was nochtans dat tussen orangisten en adepten van de Belgische revolutie. Even opvallend was de samenwerking tussen beide groepen. Die werd mogelijk dank zij twee verschijnselen. Aan de ene kant aanvaardden de orangisten de gewijzigde politieke nationaliteit; ze legden zich bij het feit België neer. Aan de andere kant erkenden de Belgische-revolutiemannen de taalkundige nationaliteit, dat wil zeggen dat zij zich voor dezelfde waarden inzetten waar het de Nederlandsgezinden vóór 1830 reeds om te doen was. In de spellingskwestie zegevierde uiteindelijk het Nederlandse standpunt.

Het taalcongres te Gent, in 1841, was een manifestatie van Vlaamse eendracht, maar een meer duurzame en concrete vorm kreeg die niet. De Vlaamsgezinden werkten eerder geïsoleerd, of in kleine lokale groepen, zonder vaste, overkoepelende organisatie. De eerste poging die, in 1844-'45, tot oprichting daarvan werd gewaagd, liep op een sisser uit: het Taelverbond, vanuit Brussel opgevat als een coördinerend lichaam, kwam niet van de grond. Een andere poging tot bundeling van de Vlaamse krachten werd vanuit Antwerpen in 1845 ondernomen door de vereniging De Toekomst. Die kreeg echter af te rekenen met een toespitsing van de politieke verhoudingen in het land, en dat was niet alleen voor De Toekomst, maar voor de Vlaamse Beweging in haar geheel het geval.

Tevoren reeds hadden Hendrik Conscience en zijn vrienden te Antwerpen een 'broederschap' gesloten, de 'Hermans' genaamd, met het oog op de leiding van de vlaamsgezinde actie. Naar de politieke overtuiging van de leden werd niet gevraagd. Eén van de resultaten was de publikatie, te Brussel in 1844, van het dagblad Vlaemsch België. De strekking daarvan was symptomatisch voor de oriëntatie van de Vlaamse Beweging tot omstreeks 1846. Partijstrijd lokte de flaminganten niet aan. Verdediging van de miskende rechten, strijd voor het behoud van eigen wezen, vereiste dat een liberale of een katholieke kleur? Laat ons 'Vlaams en vaderlands' blijven, zo luidde de algemene opvatting. 'Voor ons is het slechts een halve Vlaming, hy die de belangen des gemeenen vaderlands niet zwaer genoeg acht om in de schael van zyne genegenheid, op te wegen tegen eene andere staetkundige gezindheid' ${ }^{2}$. Partijstrijd heette onvruchtbaar en schadelijk voor het landsbelang. 


\section{DE VROEDE}

Het nationale samenhorigheidsgevoel en het herstel van de Vlaamse rechten waren er niet mee gediend. In de vlaamsgezinde gelederen was eendracht noodzakelijk en daarheen ging dan ook de hoofdbekommernis uit.

In de 'Verklaring van grondbeginselen' uit 1847 luidde het nog, dat de voorstanders van de Vlaamse Beweging als zodanig 'tot de eene noch tot de andere staetsparty' behoorden; 'zy achten hunne eigene vaderlandsche zending verheven genoeg, hunnen voorgenomen arbeid zwaer genoeg, hun doel omvattend genoeg, om tot hun aendeel in de maetschappelyke strekking voldoende te $\mathrm{zyn}^{\prime 3}$. Toen die verklaring, als resultaat van enig overleg tussen Gent en Antwerpen, werd gepubliceerd, hadden de politieke tegenstellingen echter in de schoot van de beweging reeds tot een eerste hoogoplaaiende twist geleid, naar aanleiding van het optreden van Pieter Frans van Kerckhoven te Antwerpen. Dat verschijnsel kan niet worden begrepen buiten de algemene politieke ontwikkeling van het land.

$\mathrm{Na} 1839$ begon het unionisme af te brokkelen, als gevolg van een liberale actie die door de positie van de Kerk en de houding van het episcopaat mede werd gestimuleerd. In 1846 kwam de Liberale Partij tot stand. Ze wilde de maatschappij laïciseren en daartoe de staatsmacht veroveren. Van 1847 tot 1852 was het bewind in handen van het eerste ministerie-Rogier. In de jaren vijftig volgde nog een unionistische pauze, maar sedert 1857 was het ook met de praktijk van gemengde regeringen afgelopen. De katholiek-liberale antithese zou de landspolitiek gedurende vele jaren beheersen.

De ontwikkeling van de binnenlandse verhoudingen was een eerste factor die tot de groei van politieke tegenstellingen in de schoot van de vlaamsgezinde gelederen heeft geleid. Een tweede vindt men in de nieuwe richting die de beweging zou inslaan. Ze was nog hoofdzakelijk literair, maar reeds in de jaren veertig namen Vlaamsgezinden, op lokaal vlak, hier of daar aan de verkiezingen deel. Moest men vasthouden aan een niet-politieke activiteit, of zou men de weg van de politiek opgaan? Mocht deze laatste strekking zich doorzetten, dan rees tevens het probleem van de meest adequate weg. De vraag voor welke mensen men het zou opnemen, werd meer en meer pregnant naarmate de algemene evolutie de partijpolitieke kleur van de mandatarissen of kandidaat-mandatarissen sterker en sterker accentueerde. Zich uitspreken voor een of andere groep, vooronderstelde intussen dat men had uitgemaakt welke kant men met de beweging zelf uit wilde. De liberale stroming binnen haar gelederen werd door de zucht tot 'verlichting' van het volk geïnspireerd. De katholiek-traditionalistische legde meer het accent op de trouw aan de godsdienst. Beide werden sedert de jaren veertig meer en meer aangezogen door het liberale en het katholieke denken. Of zou men aan de twee polen kunnen ontsnappen en voldoende grondslag vinden voor een eigen Vlaamse partij? Voor

3. Th. Coopman en J. Broeckaert, Bibliographie van den Vlaamschen taalstrijd, II, 1845-1852, Kon. Vl. Acad. v. Taal- en Letterkunde (Gent, 1905) 131. 
die hele problematiek betekenden de jaren vijftig een cruciale overgangstijd. Wanneer we ze overschouwen, dan valt het in de eerste plaats op, dat de afkeer van partijpolitieke actie nog in brede kring aanwezig bleef. Zulke afzijdigheid was in 1847 nog het meest voorkomend verschijnsel. De weerslag van de Februariomwenteling van 1848 hield een versterking in van de samenhorigheidswil, boven de ideologische controversen heen. Te Gent kwam gedurende de jaren vijftig felle partijschap nog niet tot uiting. Te Antwerpen brak een verzoeningstendens door. Te Brussel werkten de flaminganten als voorstanders van een niet-politiek gebonden strijd. In het midden van de jaren vijftig hield men de unionistische gedachte in uitgebreide kring nog immer boven water. Dat treft ons in de dagbladpers en in de tijdschriften; het blijkt ook uit de verklaringen van diverse personaliteiten en uit de bedrijvigheid van de Vlaamse genootschappen. De opinie, dat de Vlaamsgezinden hun programma moesten trachten te realiseren zonder de politiek erbij te betrekken, was waarlijk nog niet begraven.

In de tweede plaats constateert men dat omstreeks 1850 vernieuwde pogingen tot coördinatie werden ondernomen, op het niet-politieke vlak. Het Vlaemsch MiddenComiteit groeide uit tot een soort Vlaamse-grievencentrale en stimuleerde de petitionnementsbeweging. Al verzette Michiel van der Voort daartoe bergen werk, erg lonend lijkt dat niet te zijn geweest. Het Midden-Comiteit was in elk geval slechts een would-be staatkundige vereniging. Het Willemsfonds kwam in 1851 tot stand uit het verlangen 'om door samenvoeging der verspreide krachten, en voornamelijk door het verzamelen der noodige gelden, een magtiger werktuig aan de hand te hebben dan tot dusverre het geval was'4 . Het Willemsfonds werkte gedurende de jaren vijftig als een apolitieke, flamingantische groepering, evenwel zonder veel kracht en zonder overkoepelend karakter.

Intussen bleef de gedachte aan een onafhankelijke Vlaamse partij in een aantal geesten rondzweven. Men vindt ze gedurende de eerste helft van de jaren vijftig nog meer dan eens terug. De politieke conjunctuur in 1855-'56 - regering-De Decker en jubileumfeesten - was geschikt om ze naar voren te brengen. Het valt nochtans op, dat ze toen in de pers slechts op een paar plaatsen werd verdedigd. Zeer velen waren er blijkbaar reeds diep van overtuigd, dat het de Vlaamsgezinden onmogelijk viel, als afzonderlijke partij bij de verkiezingen in het strijdperk te treden. Een neutrale partij van alleen-maar-vlaamsgezinde leden kon slechts bestaan wanneer de haar samenstellende individuen volkomen apolitiek, liberaal noch conservatief waren, wat men zich bezwaarlijk voorstellen kan. Dat de politiek zich aan de flaminganten algemeen opdrong, valt uit de afweer daartegen af te leiden. De door velen voor de partijen betoonde minachting, bestond alleen maar in schijn. Als flaminganten konden de Vlaamse Bewegers liberaal noch katholiek zijn, als mens,

4. J. [Vuylsteke], 'De Vlaamsche Beweging. (Een vlugtige blik op haar verleden)', Nederlandsche Spectator (12 januari 1861) 1. 


\section{DE VROEDE}

als burger, waren ze het wel. In de loop van de jaren vijftig kon de partijpolitieke antithese buiten het gebied van de taalstrijd niet meer worden geweerd. Het symptomatische gebrek aan eenstemmigheid in de Vlaamse pers werd niet alleen een bestendig, maar ook een vrij algemeen verschijnsel.

De verdeeldheid betekende intussen niet dat de Vlaamsgezinden het liquideren van de Vlaamse grieven aan het bereiken van partijpolitieke doeleinden ondergeschikt maakten. Ze berustte veeleer op het feit dat ze, naar gelang van hun politieke overtuiging, een verschillende opvatting hadden over de richting die de Vlaamse Beweging zelf moest inslaan, over de verhouding die tussen de Vlaamse Beweging en de partijen moest bestaan. Volgens de liberalen was het een onbegrijpelijke dwaasheid voor de flaminganten, zich bij de katholieken aan te sluiten. Naarmate de macht van de klerikalen groeide, zou de Vlaamse zaak achteruit gaan. Die streefde immers een ideaal van verlichting na, en daarmee waren de katholieken, de 'lichtverdoovers', niet gediend. De Vlaamse Beweging had het oog op de geestesontwikkeling, de zedelijke en stoffelijke welvaart van het volk. Dat was ook het doel van de liberalen. Vlaamse Beweging en liberalisme moesten dus samengaan. Conservatieve flaminganten dachten daar evenwel anders over. De gehechtheid aan godsdienst en zedelijkheid beschouwden zij als een kenmerk van het Vlaamse volkskarakter. De Vlaamse Beweging diende dus godsdienstig, diende katholiek te zijn, zoals de Vlamingen. Konden de flaminganten niet met één, eigen partij optreden, dan bleef hun alleen over, in de conservatieve gelederen plaats te nemen.

Het blijkt dus dat de Vlaamse Beweging gedurende de jaren vijftig van een literaire beweging evolueerde naar een die ook politieke actie wilde voeren. De controverse over de doelstellingen verklaart daarbij het failliet van de pogingen tot stichting van een eigen, nationale, vlaamsgezinde partij. Waar het bewustzijn groeide dat er, in plaats van te petitioneren, aan actieve politiek moest worden gedaan, waren de beste concrete middelen daartoe aanvankelijk voor iedereen niet helemaal duidelijk. Aan het eind van de jaren vijftig kon er evenwel nog maar weinig twijfel over bestaan: toen heeft de overtuiging ingang gevonden dat de actie moest worden gevoerd binnen de twee partijen. In hun schoot zouden liberale en conservatieve flaminganten in de bres springen, om Vlaamsgezinden op de lijst van de verkiesbare kandidaten te doen brengen en, dank zij hun propaganda, op die kandidaten een zo groot mogelijk aantal stemmen te verenigen.

Terwijl het jaar 1857 de definitieve breuk betekende tussen katholiek en liberaal, gingen ook de katholieke en liberale flaminganten tegenover elkaar staan. In feite was de Vlaamse eendracht ter ziele. Voor elk van beide groepen kwam het erop aan, duidelijk te maken dat de toekomst alleen via de eigen partij veilig kon worden gesteld. Papieren argumenten hadden echter weinig waarde. Wat konden de toenmalige Vlaamsgezinden immers in het ene of het andere kamp bereiken? In beide bleven ze vooralsnog een minderheid die zo goed als van geen tel was. Dat nam 
intussen niet weg, dat de Vlaamse beginselen voortaan waren ingeschakeld in een groter geheel. Het samenkoppelen van vlaamsgezindheid met liberalisme aan de ene kant en met katholicisme aan de andere, verscherpte evenwel de tegenstellingen, waar de verschillende politieke ideologie de gemeenschappelijke vlaamsgezindheid in de schaduw stelde.

Omstreeks 1860 brak aldus een nieuwe periode aan: in elke partij zou de strijd gevoerd worden om politieke macht voor de Vlaamse Beweging. Gedurende de twee eerstvolgende decennia trad het liberale flamingantisme sterk op de voorgrond. Julius Vuylsteke propageerde de vereenzelviging van de Vlaamse met de liberale gedachte. Aan de andere kant werd de tegenovergestelde affirmatie: 'Vlaams is katholiek', gedurende de jaren zestig nog niet even sterk beklemtoond, maar dat volgde spoedig, in verband met de opkomst van het ultramontanisme. Binnen de katholieke gelederen kwamen de flaminganten langzamer op gang. De oprichting van het Davidsfonds, tegenover het inmiddels liberaal geworden Willemsfonds, dateert van 1875.

Veeleer dan bij de toespitsing van de partijpolitieke tegenstellingen, hoewel dat de dominante was, zouden we willen stilstaan bij de pogingen, gedurende de jaren zestig aangewend, om nog iets te realiseren van de eendracht. Kon men zich nog uit de macht van de partijgeest bevrijden? De droom was klaarblijkelijk niet uitgestorven. Aan een eigen Vlaamse macht viel echter alleen nog maar te denken mits aanpassing aan het partijwezen.

In dat verband gaat onze aandacht allereerst uit naar het Vlaemsch Verbond, dat uit 1861 dateert. In die vereniging waren alle Vlamingen welkom, tot welke partij ze ook behoorden. Alleen werd hun gevraagd dat ze bij verkiezingen hun stem niet zouden uitbrengen op kandidaten die qua vlaamsgezindheid geen vertrouwen verdienden; men zou zich liever onthouden. Het Vlaemsch Verbond was opgevat als een over alle Vlaamse gewesten uitgebreide organisatie, met lokale afdelingen en comité's die bij verkiezingen de kandidaten van elke kleur zouden bewerken. Daarbij werd tevens een hoofdcomité voorzien, dat de activiteit van de diverse afdelingen zou superviseren. Dat plan werd evenwel reeds tijdens de eerste algemene bijeenkomst gekelderd. Overtuigd van het belang van politieke actie, streefde het Vlaemsch Verbond ernaar, samenwerking van de flaminganten te realiseren, de opdringende partijgeschillen ten spijt. Dat streven is mislukt; te Gent leed de samenwerking al dadelijk schipbreuk. In globo is het een onverkwikkelijke geschiedenis geworden, wat meegebracht heeft dat een centrale organisatie in de Vlaamse Beweging is blijven ontbreken.

Dat betekent echter niet dat er hoegenaamd geen samenwerking meer was. We dienen inderdaad attent te zijn op de ontwikkeling te Antwerpen. Daar bleef niet alleen de gedachte voortleven, maar men vernieuwde ook de pogingen die er gedurende de jaren vijftig steeds met dezelfde bedoelingen waren aangewend. In 


\section{DE VROEDE}

het voorjaar van 1861 werd de Nederduitsche Bond gesticht. Zijn opzet en doelstellingen waren niet dezelfde als die van het Vlaemsch Verbond. De Nederduitsche Bond, die zich als een onafhankelijke vereniging voor de Vlaamse rechten wilde inzetten, heeft daarbij, ook buiten Antwerpen, een samengaan van de Vlaamsgezinden gestimuleerd.

Alvorens we daarop ingaan, dient echter te worden aangestipt hoezeer de lokale Antwerpse situatie van aard was om een dergelijke hergroepering in de hand te werken. De Nederduitsche Bond kwam tot stand in een periode van politieke gisting. De omstandigheden werkten er het ontstaan van een partijcoalitie in de hand, door de agitatie van de meetings in verband met de fortenkwestie. De Meetingpartij verenigde katholieken en liberalen. In haar schoot verkreeg de Nederduitsche Bond een zelfstandige positie. Hij zelf omvatte Vlaamsgezinden van diverse opinie. Men trof er nagenoeg alle Antwerpse flaminganten aan, althans tot eind 1864. Toen brokkelde de samenwerking af, om in 1866 op dissidentie uit te lopen. Er kwam een aparte Liberale Vlaamsche Bond tot stand, zoals te Gent.

Het Antwerpse succes gedurende de eerste jaren zestig volstond echter om de actie te verwijden, met andere woorden om ook in andere centra Vlaamsgezinden van diverse pluimage tot samenwerking te bewegen. Men dient die stroming te zien in het licht van een meer algemene politieke ontwikkeling. Tegen de tendens van de doctrinair-liberale regering verenigden zich radicale liberalen met progressistische katholieken. Beide elementen stuurden aan op een meer democratische koers; beide betuigden ook hun sympathie voor het streven van de Vlaamse Beweging. De flaminganten lieten zich daarbij niet onbetuigd, traden in meer dan één geval zelfs als mentors op. Aldus was een gunstig klimaat geschapen voor de actie van wat een onafhankelijke volkspartij werd genoemd. Uit de jaren zestig vallen ook te Brugge en te Brussel diverse initiatieven te noteren, geïnspireerd door dat nieuwe bondgenootschap. Een werkelijke partijstructuur heeft die zogenaamde onafhankelijke volkspartij nochtans niet gekregen en het bedoelde samengaan is reeds omstreeks het midden van de jaren zestig verlopen.

Op het meer beperkte terrein van de flamingantische actie waren landdagen het middel dat tot organisatie van de samenwerking werd beproefd. Sterker dan in liberaal-radicale en katholiek-progressistische milieus leefde hier de gedachte voort van een nationale unie, of althans de opvatting dat de Vlaamse belangen, als een suprapolitieke waarde, de voorrang verdienden. De Nederduitsche Bond verleende de krachtigste impuls tot die landdagen. Het waren langdurige bijeenkomsten, in diverse steden, waartoe de vooraanstaande flaminganten en de verenigingen van het hele Vlaamse land werden opgeroepen. Het zijn manifestaties geweest van Vlaamse eendracht, zowel over de provincie- als over de partijgrenzen heen. Maakt men de balans op, dan constateert men niettemin dat concrete resultaten uitbleven, in die betekenis dat ook de landdagen de doorwerkende partijtegenstellingen binnen de Vlaamse gelederen niet konden overbruggen. 
Te Antwerpen leidde de daareven geschetste coalitie tot een doorbraak van meer dan lokale betekenis. De politieke activiteit van de Nederduitsclie Bond en van zijn gekozenen heeft echter het ontbreken van een centraal coördinerend Vlaams orgaan slechts ten dele kunnen verhelpen. Wat te Antwerpen slaagde, mislukte elders. Nergens heeft zich de reële mogelijkheid voorgedaan om uit de coalitie van antiregeringsgezinden een nieuwe partij te zien groeien. De politieke sfeer liet dat uiteindelijk niet toe. Gedurende de jaren zestig en zeventig werden de verhoudingen met de dag meer gespannen. Het liberale radicalisme prikkelde de katholieken tot scherpere reactie. Van een Vlaams eenheidsfront op het politieke terrein viel aldus na 1870 vrijwel niets meer te bespeuren. Een eigen Vlaamse partij vond alleen te Brussel nog aanhangers. De Vlaamsgezinden waren er dun gezaaid; de meesten leken er tot het vrijzinnige, progressistische kamp te behoren. In hun reactie tegen het voortschrijden van de verfransing, neigden ze gemakkelijk tot Vlaams radicalisme. Tijdens de beginjaren zeventig propageerde de maatschappij De Veldbloem in de hoofdstad een Vlaamsche Volkspartij, tot realisatie van een vlaamsgezind, progressistisch programma. De zich toespitsende liberaal-katholieke antithese maakte dat streven echter illusoir. De Veldbloem zelf zou omstreeks 1880 haar vroegere koers verloochenen, om tot het orthodoxe liberale kamp toe te treden.

Wat de resultaten betreft van de politieke actie der flaminganten, gedurende de jaren zestig en zeventig, valt dus te noteren dat liet optreden in coalitieverband alleen te Antwerpen vruchten heeft afgeworpen. Daar werden enkele overtuigde Vlaamsgezinden tot parlementslid gekozen. Dat was overigens ook onrechtstreeks van belang: hun optreden in de Kamer liet toe de vlaamsgezinde agitatie te versterken, wat ertoe bijdroeg aan de Vlaamse zaak in het land een politieke betekenis te geven. De resultaten van de afzonderlijke actie, in eigen partijverband, waren veeleer negatief. Tijdens de jaren die het hoogtepunt vormden van het Vlaamse liberalisme, hebben de liberale Vlaamsgezinden wel een zelfstandige groep opgebouwd binnen hun eigen partij - de Liberale Vlaamse Bonden sloten zich in 1882 tot een federatie samen - maar ze slaagden er niet in die partij voor de Vlaamse zaak te winnen. Binnen de katholieke gelederen constateert men hetzelfde verschijnsel. Het kwam daar niet eens tot een bundeling van de krachten. De Katholieke Vlaamsche Landsbond dateert van 1891. Het zij overigens opgemerkt dat de Katholieke Partij als zodanig eigenlijk pas in 1885 tot stand kwam. Men kan besluiten dat de actie van de Vlaamsgezinden tot verovering van de partijen mislukte. Veeleer het omgekeerde deed zich voor: de belangen van de partij kregen de voorkeur boven de Vlaamse. Dat droeg ertoe bij dat een gezamenlijke actie voor flaminganten van verschillende kleur wel erg moeilijk werd. Er hadden dan ook haast geen manifestaties plaats, waar ze zijde aan zijde stonden. Laten we als glanspunt de Consciencefeesten uit 1881 vermelden, juist op een moment dat de schoolstrijd alle samenwerking utopisch leek te maken. 


\section{DE VROEDE}

De balans van het politieke optreden in eigen partijverband was nochtans niet helemaal negatief. Liberale actie wekte katholieke reactie. De partijnaijver werkte het tot stand komen van de eerste drie taalwetten in de hand. In het algemeen verleende het overschakelen naar de partijpolitiek aan de Vlaamse kwestie een grotere politieke actualiteit.

$\mathrm{Nu}$ valt het niet te loochenen dat de eerste drie taalwetten meer dan één Vlaamsgezinde hebben teleurgesteld. Velen toonden zich overigens reeds diep ontgoocheld over de houding van de politieke partijen. Had het eigenlijk zin dat, aan de basis, liberale en katholieke flaminganten elkaar bestreden, terwijl de mandatarissen van beide soorten in gebreke bleven? Kon men toch niet beter samenwerken, boven de partijen heen, of zelfs daarbuiten? Die gedachte vond een voedingsbodem in de ontstemming over het niet-toepassen van de taalwetten, wat vooral na de goedkeuring van de wet van 1883 duidelijk werd. Vrij algemeen misnoegen schiep aldus, in de jaren tachtig, een gunstiger atmosfeer met het oog op eventuele samenwerking. De wenselijkheid daarvan werd uit diverse hoek beklemtoond. Ging men dan op weg geraken naar een eigen Vlaamse politieke groepering, of zou men, in een andere vorm, ten minste coördinatie weten te realiseren?

Overschouwen we de laatste drie decennia vóór 1914, dan constateren we, aan de ene kant, dat de politieke strijd langs de traditionele weg werd voortgezet en, aan de andere kant, dat het tot meer en tot sterker samenwerking kwam dan tevoren.

In verband met het eerstgenoemde aspect van die periode, wil het ons voorkomen dat het ontstaan en de ontwikkeling van de Belgische Werkliedenpartij, van de christen-democratie en van haar afgescheurde tak, het daensisme, hier niet een bijzondere behandeling vragen. Men weet dat ook de socialisten zich voor Vlaamse desiderata hebben ingezet, maar hun partij als zodanig was er niet een van Vlaamsgezinden. Dat geldt ook voor de christen-democraten, terwijl het bij de daensisten tot een verstrengeling kwam van Vlaamse en democratische gezindheid. In alle nieuwe partijen lag het accent op de sociale en de sociaal-politieke actie. Er zij verder aan herinnerd, dat de invoering van het meervoudig algemeen stemrecht en van de evenredige vertegenwoordiging de verhoudingen in de schoot van het partijwezen sterk heeft beïnvloed, terwijl ze in politicis aan 'het Vlaams' een meer pregnante betekenis gaf. Terwijl de katholieken in globo hun posities handhaafden, braken de socialisten door en gingen de liberalen achteruit. De problematiek van de Belgische partijpolitieke strijd werd vóór 1914 nochtans niet grondig gewijzigd.

Er kan evenmin sprake zijn van een vernieuwing in de schoot van de Vlaamse Beweging, wat het politieke optreden van haar aanhangers betreft. De politieke strijd - op de afzwakking van de belangstelling daarvoor komen we straks terug werd, tot bevordering van de Vlaamse belangen, steeds gevoerd volgens het vertrouwde patroon: ieder via de eigen organisaties en vasthoudend aan de eigen ideologie. Dat de Vlaamse zaak aldus het best werd gediend, was de meest ver- 
spreide opvatting. De praktijk gaf dan ook de toepassing daarvan te zien, zowel bij katholieke als bij niet-katholieke Vlaamsgezinden.

Intussen valt het op - en dat is het tweede aspect van de periode - dat samenwerking herhaaldelijk tot stand kwam. Hoofdzaak in dat verband waren nog niet zozeer de talrijke optochten en feestvieringen. Men beleefde weliswaar het beschamende verschijnsel dat, als resultaat van een vinnige polemiek, de Slag der Gulden Sporen te Kortrijk in 1902 niet gezamenlijk werd herdacht, maar door katholieke, liberale en socialistische Vlamingen afzonderlijk, telkens vanuit een verschillende levensbeschouwing. Daartegenover kan men evenwel een hele lijst aanleggen van manifestaties waar Vlaamsgezinden van diverse pluimage zijde aan zijde stonden geschaard, of broederlijk tezamen opstapten. De Benoitfeesten in 1892 en 1897, de inwijding van Snellaerts praalgraf in 1896, het Ledeganckfeest in 1905, de Consciencefeesten in 1912, de hulde aan Hugo Verriest in 1913: het zijn voorbeelden die met vele andere kunnen worden aangevuld. Bij dergelijke gelegenheden bleek duidelijk dat 'rechtse' en 'linkse' Vlaamsgezinden zich rondom erkende figuren - hun gemeenschappelijk bezit - konden verenigen; er ging dan ook een stimulans van uit. Laten we nochtans opmerken dat meestal de retoriek er hoogtij vierde, zonder dat een diepe bezinning daarmee gepaard ging.

Meer betekenis zal men dan ook hechten aan de verschijnselen van meer realistische samenwerking, in de parlementaire actie en in de agitatie daaromheen of daarbuiten. Het schitterendste voorbeeld geeft ons de strijd voor de gelijkheids wet, in 1896-'98. Het kwam daarbij niet tot een versmelting van liberale, katholieke, christen-democratische en socialistische Vlaamsgezinden. Zelfs een ideologische toenadering viel niet te bespeuren: in iedere groep handhaafden de flaminganten hun partijpolitieke opvattingen ongewijzigd. Wel werden de krachtsinspanningen gebundeld, met het oog op een gemeenschappelijk doel. Het belang van de gelijkheidswet lag vooral op het morele vlak. De evidente gegrondheid van haar beginsel heeft de Vlaamse actie toenmaals een nationaal impuls geschonken, over de politieke opvattingen en levensbeschouwingen heen.

Een goed decennium later werden de krachten andermaal gebundeld, met het oog op de vernederlandsing van de universiteit te Gent. Iedereen die van de ontwikkeling der Vlaamse Beweging ook maar iets afweet, is vertrouwd met het beeld van de drie kraaiende hanen ${ }^{5}$. Hun optreden maakte deel uit van een meetingbeweging waarin sprekers van diverse gezindheid de idee van de vernederlandsing samen over het land uitdroegen. Naar de woorden van Lodewijk de Raet had een beweging in Vlaanderen nooit 'een zoo algemeen en nationaal karakter' gedragen.

Verder zij herinnerd aan een derde, minder bekend, maar even illustratief ver-

5. Frans van Cauwelaert, Louis Franck en Camille Huysmans. Men kan overigens van vier hanen spreken: de Antwerpse liberaal Leo Augusteyns heeft zich vaak voor L. Franck ingezet; er bestaan prentbriefkaarten waarop hij, en niet Franck, samen met de andere twee afgebeeld staat. 


\section{DE VROEDE}

schijnsel: de eensgezinde actie van de Vlaamsgezinden, in 1912, met het oog op de wereldtentoonstelling die te Gent het jaar nadien zou plaats hebben. Zij kwam los toen het bleek dat de organiserende instanties de Nederlandse taal volledig miskenden. Die situatie werd recht gezet dank zij het optreden van een Vlaams comité waarin alle grote organisaties vertegenwoordigd waren: het Davidsfonds, het Willemsfonds, het Algemeen Nederlandsch Verbond, het Nationaal Vlaamsch Verbond.

Waarin moeten we de verklaring zoeken van de Vlaamse samenwerking? Gemeenschappelijke vlaamsgezindheid leidde tot akkoord over de inzet. Het zij daarbij opgemerkt dat de boven uitgestippelde algemene opvatting: elk de strijd voeren in eigen partij, niet zover ging dat, met het oog op concrete doeleinden, samenwerking in principe werd uitgesloten. De tegenstellingen hoefden niet te worden opgeofferd om, onder gewichtige omstandigheden, voor welbepaalde objectieven een tijdelijke bundeling van krachten mogelijk te maken. Tenslotte dient men rekening te houden met die Vlaamsgezinden die hun Vlaamse overtuiging boven hun politieke de voorrang gaven, of die meer dan occasionele samenwerking van alle flaminganten wenselijk en noodzakelijk achtten. Ze vormden een kleine minderheid, maar hun optreden was niet zonder betekenis.

In dat verband moet men een onderscheid maken tussen, aan de ene kant, nietpolitieke organisaties waarin flaminganten van verschillende richting geregeld samenwerkten, en, aan de andere kant, de pogingen tot samengaan met het oog op politieke objectieven, waarbij de gedachte van een radicaal-Vlaamse partij bij sommigen inspirerend heeft gewerkt.

Uit de eerste sector zij, exemplarisch, alleen gewezen op de activiteit van het Algemeen Nederlandsch Verbond, dat in 1895 werd opgericht. Het ANV heeft op brede schaal propaganda gevoerd. Het was vóór de Eerste Wereldoorlog een stimulerend element in de Vlaamse Beweging, onder meer in de strijd voor de gelijkheidswet en voor de vernederlandsing van de universiteit te Gent. Zijn werking droeg niet alleen bij tot de verspreiding van de Nederlandse gedachte in de Vlaamse gewesten, maar ze was daar in ten minste even grote mate op de vooruitgang van de Vlaamse Beweging gericht.

Wat de tweede sector betreft, dient onze aandacht uit te gaan naar de landdagbeweging. Op de eerste landdagen uit de jaren zestig hebben we reeds gewezen. Gedurende de jaren zeventig was de beweging verlopen, maar tijdens het daaropvolgende decennium, meer bepaald sedert 1886, nam ze opnieuw uitbreiding. De jaarlijkse landdagen waren trefpunten van Vlaamsgezinden van verschillende opinie, waarbij zij aangestipt dat de liberale aanbreng alleen vanuit Brussel betekenis had. Aan politiek werd tijdens die bijeenkomsten niet veel gedaan, maar alleen reeds het feit dat ze plaats hadden betekende propaganda voor niet-partijgebonden Vlaams radicalisme. In 1889 kreeg de beweging een vastere organisatie door de 
oprichting van een centraal comité. Een politiek lichaam is dit niet geworden. Wel riep het in 1890 een Nationaal Vlaamsch Verbond in het leven, dat tot in 1914 is blijven bestaan. Dit Verbond, dat samenwerking - niet versmelting - van de Vlaamsgezinden zo veel mogelijk wilde realiseren, heeft zich in de partijpolitiek evenmin laten gelden. In het raam van de beweging rondom de taalwetten heeft het evenwel, via studie- en actiecomité's, veel werk verzet. De partijgeest bleef daaraan vreemd, terwijl uit alle Vlaamse gewesten medewerking werd verleend.

Ingevolge een besluit van de landdag van april 1892, te Brussel, ruimde het centraal bestuur van de landdagen de baan voor een Vlaamsche Volksraad, een soort vertegenwoordigend lichaam van de Vlaamsgezinden, waar de voor hen belangrijke aangelegenheden ter discussie zouden komen. Met de hulp van comité's van het Nationaal Vlaamsch Verbond zou de actie van de flaminganten aldus worden gecoördineerd. Succes buiten de landdagmilieus is echter uitgebleven. De Vlaamsche Volksraad, die zoals het Verbond tot 1914 fungeerde, werd aldus een wouldbe-parlement, een vereniging naast andere. Men bestudeerde er de hangende problemen, maar politieke kracht werd er niet ontwikkeld.

Te Brussel, doch daar alleen, is onder invloed van de landdagbeweging een onzijdige, zelfstandige Vlaamse partij tot stand gekomen, vooral onder aandrang van de vrijzinnige flaminganten. De Vlaamsche Volkspartij, zoals die groepering heette, heeft vóór en na de eeuwwisseling zonder succes aan verkiezingen in de hoofdstad deel genomen. Betekenis heeft ze vrijwel niet verworven.

In globo heeft de landdagbeweging een aanzienlijke bijdrage geleverd tot de Vlaamse strijd. Haar aanhangers hebben de idee van samenwerking naar buiten uitgedragen; ze werkten de verzuiling van de Vlaamse Beweging in het partijwezen tegen. Tot het gezamenlijke optreden in de campagne voor een vernederlandste universiteit heeft de landdagbeweging het terrein geëffend. Haar propaganda heeft, ook daarbuiten, de Vlaamse Beweging omstreeks de eeuwwende tot bredere bevolkingslagen helpen doordringen.

Naast de voortzetting van de politieke strijd langs de traditionele wegen en een steeds sterker wordende tendens tot groepering van de krachten boven de politiek, constateren we in de laatste decennia vóór de Eerste Wereldoorlog ook nog een verzwakking van de geestdrift voor, en zelfs een aikeer van de politiek als middel tot realisatie van de flamingantische doelstellingen. Symptomatisch in dat verband waren de Kritiek der Vlaamsche Beweging, door August Vermeylen in 1895 geschreven, en de theorie van de zelfcultuur die Frans van Cauwelaert tijdens de beginjaren 1900 naar voren bracht.

De mening van Vermeylen, 'dat de Staat-als-gezag in afzienbaren tijd ineenstorten zal', kon licht de overtuiging bijbrengen dat parlementaire actie met het oog op verdere vernederlandsing geen zin had. Al verwierp hij die mening in $1905^{6}$, toch 6. In het woord vooraf tot de afzonderlijke uitgave van de Kritiek (Bussum, 1905). 


\section{DE VROEDE}

handhaafde hij zijn pleidooi tegen de al te beperkte strijd voor taalwetten en voor een verruiming van de Vlaamse Beweging tot 'een maatschappelijk streven in den breedsten zin van 't woord' ${ }^{7}$, wat het bewustworden van elke Vlaming onderstelde. Volgens Van Cauwelaert moest de Vlaamse Beweging bovenal 'een strijd voor zedelijke zelfhervorming' zijn. Politieke actie bracht geen aarde aan de dijk zonder voorafgaande innerlijke gezondmaking van het volk. Op de ontwikkeling van het stambewustzijn bij elk individu, daarop kwam het aan. Zulke beklemtoning van de zelfcultuur, als basis van de sociale hervorming, kon uitlopen op een cultuurflamingantisme dat, in zijn afwijzen van de politiek, aan de Staat al te weinig betekenis toekende. In dat verband zij opgemerkt dat Van Cauwelaert, al moge hij geringschattend hebben gestaan tegenover de politiek, in 1910 toch zelfde parlementaire weg is opgegaan. Zijn praktische houding was niet een geheel consequente toepassing van de theorie van een zuivere zelfcultuur. Anderdeels bewoog hij zich binnen het traditionele patroon, waarop we dadelijk terugkomen.

Brengt men zich de ontwikkeling tijdens en na de Eerste Wereldoorlog voor de geest, dan kan niet het cultuurflamingantisme als voorbode van een tendens tot vernieuwing van de Vlaamse actie worden beschouwd. Men zal dan veeleer denken aan het radicalisme dat van het traditionele patroon wèl is afgeweken, met andere woorden aan de kiemen van het Vlaams-nationalisme.

De negentiende-eeuwse Vlaamse Beweging was een reformistische beweging. Ze werd aanvankelijk gekenmerkt door een loyale Belgische gezindheid van haar aanhangers. De Belgische bezieling begon sedert de jaren vijftig wel af te brokkelen, maar de visie van de flaminganten, het kader waarbinnen ze hun beweging wilden zien groeien, bleef Belgisch, ook toen ze de weg van de politiek opgingen. Het partijwezen was immers Belgisch, niet Vlaams, of Waals. Dat droeg er in sterke mate toe bij om de Vlaamse Beweging buiten een nationalistisch-Vlaamse, of-Nederlandse, koers te houden. Ze is dan ook, tot aan de Eerste Wereldoorlog, blijven streven, niet naar een verandering van de staatsstructuur, doch naar hervormingen daarbinnen, waarbij men dan nog slechts langzaam evolueerde van 'In Vlaanderen Vlaams' naar 'Vlaanderen Vlaams'. Het valt dan ook op te merken, dat omstreeks de eeuwwisseling reeds stemmen opgingen die een verandering van de structuur zelf van de Staat niet ongenegen waren. Dat was met een aantal jongeren het geval. De flaminganten die zich ten voordele van een bestuurlijke scheiding uitspraken, bleven vóór 1914 weliswaar uitzonderingen, maar het probleem was gesteld. Zou het uiteindelijk een nieuwe splijtzwam drijven in de vlaamsgezinde gelederen?

Wie tijdens de Eerste Wereldoorlog activist werd, kwam vooral uit het kamp waar de Vlaamse actie zich buiten de partijen om ontwikkeld had. Zij die vóór 1914 in de partijpolitiek bedrijvig waren geweest, hielden het bij het zogenaamde passi-

7. Ibidem, 25 . 
visme. Na de oorlog brachten Vlaamsgezinden van diverse politieke gezindheid het Algemeen Vlaamsen Verbond op de been, dat zich zou inzetten voor de realisatie van het bekende minimumprogramma. Dat Verbond is er niet in geslaagd de actie van de flaminganten uit de afzonderlijke partijen te coördineren. Het verdween zonder veel sporen na te laten. Het akkoord over het minimumprogramma bleef nochtans bestaan, maar de verschillende soorten flaminganten die men onder de noemer Vlaams-belgicisten kan vangen, waren gebonden door de andere belangen van hun partijen. De negentiende-eeuwse verschijnselen werkten door.

Aan de andere kant ontwikkelde zich de Frontpartij. Een kans tot actie in de schoot van de minimalistische organisaties heeft ze niet gekregen. Dat ze, wat betreft andere politieke vraagstukken dan het Vlaamse, het standpunt van de zogenaamde godsvrede innam, betekende dat ze de traditionele partijtegenstellingen uit de weg wilde gaan. De Fronters hadden liefst een algemeen-Vlaamse partij tot stand zien komen, maar dat bleek een onmogelijke zaak. Zo is het Vlaamsche Front slechts de radicale vleugel geworden van de toenmalige Vlaamse Beweging. Al spoedig was een terugkeer naar de gevestigde partijen voor de Fronters uitgesloten.

Men weet dat, tussen de beide wereldoorlogen, en vooral naar 1940 toe, de kloof tussen Vlaams-belgicisten en Vlaams-nationalisten groter is geworden. Het ging immers, in tegenstelling tot de ontwikkeling vóór 1914, niet meer alleen om verschil van ideologie en om verschil van tactiek binnen de gegeven staatsstructuur en in het raam van het gevestigde partijbestel. De nationalisten verwierpen de Belgische unitaire Staat en keerden zich uiteindelijk ook in toenemende mate tegen het parlementair-democratische regime.

Hoe stond het dan met de samenwerking gedurende het interbellum? Dat de Vlaamsgezinden uit de diverse traditionele partijen hun krachten herhaaldelijk hebben gebundeld, blijkt uit talrijke voorbeelden, die voldoende bekend zijn. Laten we alleen herinneren aan de realisatie van de taalwetten uit de jaren dertig, of aan de actie voor amnestie. Van samenwerking tussen Vlaams-belgicisten en Vlaamsnationalisten viel echter weinig of niets te bespeuren. De Vlaamse concentratie uit 1936 was een vrijwel doodgeboren kind. We verliezen daarbij niet uit het oog dat maximalisten en minimalisten het in de grond eens waren betreffende een hoofdobjectief: de volledige vernederlandsing van de Vlaamse gewesten. De nationalisten kozen echter hun eigen weg; zij kunnen niet worden beschouwd als de erfgenamen van de flaminganten die vóór 1914 de voorrang van de 'nationale' waarden hadden beklemtoond.

Ons besluit, waarbij we de beperkingen, aan onderhavige bijdrage gesteld, gaarne in herinnering brengen, zal kort zijn:

1. Het succes van de politieke Vlaamse Beweging kan niet aan een eenheidsformatie worden toegeschreven, noch vóór noch na de Eerste Wereldoorlog. 
2. De ontwikkeling van die beweging werd in sterke mate door het Belgische partijwezen bepaald. Ze miste de kracht om dat partijwezen te doorbreken.

3. Niettemin valt doorheen haar geschiedenis de tendens tot samenwerking van alle Vlaamsgezinden duidelijk te volgen. Gemeenschappelijk optreden in de praktijk gaf vorm aan een doorlopend streven naar overkoepeling van de partijtegenstellingen. Dat verschijnsel mag als een vaste traditie worden beschouwd.

\section{Literatuur}

Algemene werken over de ontwikkeling van de Vlaamse Beweging, of studies betreffende haar aspecten, vindt men, voor zover verschenen vóór het einde van de jaren 1950, aangegeven in M. de Vroede, Bibliografische inleiding tot de studie van de Vlaamse Beweging, 1830-1860 (Interuniversitair Centrum voor hedendaagse geschiedenis, Bijdragen VIII; Leuven-Parijs, 1959) 9-20. Een oriëntatie in het belangrijkste dat nadien werd gepubliceerd, geeft A. W. Willemsen, 'De geschiedenis van de Vlaamse Beweging tot 1914. Een overzicht van recente literatuur', Tijdschrift voor Geschiedenis, LXXXIII (1968) 306-333.

Wat de ontwikkeling vóór 1914 betreft, afgezien van de Oostenrijkse, de Franse en de Nederlandse tijd, blijft het werk van P. Fredericq, Schets eener geschiedenis der Vlaamsche Beweging (Victor De Hoon-fonds; 3dln, Gent, 1906-1909) onmisbaar voor de feitenkennis. Tot voor kort waren de beste synthesen: S. B. Clough, A History of the Flemish Movement in Belgium. A Study in Nationalism (New York, 1930) en L. Picard, Geschiedenis van de Vlaamsche en Groot-Nederlandsche Beweging (2 dln; Antwerpen, 1937, 1942²-1959), vooral dl. I, over de periode tot ca. 1870. Van een nieuwe aanpak getuigde L. Wils, De ontwikkeling van de gedachteninhoud der Vlaamse beweging tot 1914 (Kathol. Vlaamse Hogeschooluitbreiding, verh. 442-443; Antwerpen, 1955). Thans beschikt men over het uitvoerige en grondige werk van H. J. Elias, Geschiedenis van de Vlaamse gedachte, 1780-1914 (4 dln; Antwerpen, 1963-1965), dat nochtans, zoals de auteur zelf beklemtoont, niet een algemene geschiedenis van die beweging is. Betreffende de tijd vóór 1914 ligt die nog niet voor. Het wetenschappelijk onderzoek is sedert een goed decennium echter sterk vooruit gegaan.

De ontwikkeling na 1914 wordt uitvoerig beschreven in twee recente synthesen: A. W. Willemsen, Het Vlaams-nationalisme. De geschiedenis van de jaren 1914-1940 (Utrecht, $1969^{2}$ ) en H. J. Elias, Vijfentwintig jaar Vlaamse Beweging 1914-1939 (Coll. Mens en Tijd; $4 \mathrm{dln}$, Antwerpen, 1969). De eerste studie is veel ruimer dan men uit de titel zou kunnen afleiden. De tweede mag niet worden beschouwd als de voortzetting van het reeds vermelde werk van dezelfde auteur. Zie mijn bijdrage in dit tijdschrift, LXXXV (1970) 337-345.

Voor nadere informatie betreffende onderdelen van de behandelde stof zij bovendien verwezen naar: L. Wils, De politieke oriëntering van de Vlaamse Beweging (1840-1857) (Kathol. Vlaamse Hoogeschooluitbreiding, verh. 467; Antwerpen, 1959); Idem, Kanunnik Jan David en de Vlaamse Beweging van zijn tijd (Keurreeks van het Davidsfonds, LXVII; Leuven, 1957); M. de Vroede, De Vlaamse Beweging in 1855-1856. Bijdrage tot een meer verantwoorde kennis van haar evolutie (Verhandelingen van de Kon. Vl. Academie v. Wetenschappen, Letteren en Schone Kunsten v. België, Klasse der Letteren, XLI; Brussel, 1960); L. Wils, Het ontstaan van de Meetingpartij te Antwerpen en haar invloed op de Belgische politiek (Antwerpen, 1963); Idem, 'Tussen taalstrijd en arbeidersbeweging: 
'de onafhankelijke volkspartij' in de jaren 1860', Bijdragen tot de geschiedenis inzonderheid van het oud hertogdom Brabant, 3de reeks, XIII, iv (1961) 147-184; Idem, 'Bij de 40e verjaring van het overlijden van Lod. De Raet. De Landdagbeweging, het Daensisme en de Vlaamsche Volkspartij', Kultuurleven, XXII (1955) 202-214; Idem, Het daensisme. De opstand van het Zuidvlaamse platteland (Keurreeks van het Davidsfonds, CX; Leuven, 1969); M. de Vroede, Juliaan De Vriendt in de politiek en de Vlaamse Beweging (18891900) (Antwerpen, 1960). 


\section{Recensies}

Monasticon beige, Tomé IV, Province de Brabant, quatrième volume (Luik: Centre National de Recherches d'Histoire Religieuse, 1970, in-4º, blz. 865-1155, 550 Bfr.).

In dit nieuwe deel van het Monasticon vindt men 10 notities over de reguliere kanunniken van Sint-Augustinus, nl. over de Sinte-Gertrudisabdij te Leuven, de abdij van Sint-Jakob op de Koudenberg, de Onze-Lieve-Vrouwabdij te Bellingen, de priorij van Bethleem te Herent, de priorij van Bois-Seigneur-Isaac te Ophain-Bois-Seigneur-Isaac, de priorij van Groenendaal te Hoeilaart, de priorij van Roodklooster te Oudergem, de priorij van Zevenborre te Sint-Genesius-Rode, de priorij van de Dalscholieren te Zoutleeuw en de priorij van Sint-Maartensdal te Leuven. Deze bijdragen zijn uiteraard van ongelijke waarde en lengte (tussen 96 en 10 blz.). Men kan inderdaad van mening verschillen over de vraag of het de bedoeling van dit verzamelwerk moet zijn zo volledig mogelijke monografieën te bieden, dan wel een bibliografisch hulpmiddel en een lijst van oversten als kader voor verdere studie. Wat er ook van zij, een notitie is steeds nuttig wanneer ze op een overzichtelijke wijze een status questionis biedt. De overzichtelijkheid zou echter wel heel wat kunnen verbeterd worden door een duidelijker typografische weergave van de ondertitels. In het huidige systeem springen enkel de namen van de oversten in het oog, doch niet de onderverdeling van het eerste gedeelte met de bibliografie en de bronnenopgave.

Bij de medewerkers aan het Monasticon verneemt men ook wel eens enige kritiek op het verwijzingssysteem in dit verzamelwerk. Niet alleen is de volgorde: jaargang of deel, bladzijde, plaats van uitgave, datum van uitgave, ongebruikelijk buiten de Luikse Universiteit, maar vooral de methode om het verwijzingscijfertje in de tekst nooit bij een getal te plaatsen, stoot wel eens op weerstand bij de auteur, die soms juist die datum of dat getal door een voetnoot wil gestaafd zien. De bedoeling is natuurlijk de verwarring te vermijden die zou kunnen ontstaan wanneer twee getallen naast elkaar worden geplaatst. Doch de mogelijkheid tot vergissing is niet zo groot, vermits de verwijzing naar de voetnoot steeds tussen haakjes staat, en deze mogelijkheid zou wellicht helemaal kunnen uitgeschakeld worden door de kleinere cijfertjes uit de voetnoten ook voor de verwijzingen in de tekst te gebruiken. De methode om geen idem of ibidem in de voetnoten te dulden is op zichzelf lofwaardig en maakt het de lezer gemakkelijk, doch brengt wel mee dat onderaan sommige bladzijden een tiental keren dezelfde vrij lange verwijzing staat. Hiervoor ware de oplossing wellicht de volledige verwijzing in de eerste voetnoot van elke bladzijde te herhalen en telkens wanneer de reeks door een andersoortige voetnoot onderbroken werd, doch voor het overige het ibidem toe te laten.

Een archivaris zal bij het lezen van zulk verzamelwerk ook met enige angst denken aan de ontelbare keren dat sommige oorspronkelijke documenten voor zulk werk moesten worden gemanipuleerd, soms alleen maar voor het opzoeken van een naam of een datum. Dit bezwaar had wellicht bij de oorspronkelijke planning van het werk ondervangen kunnen worden, door eerder per fonds alle gegevens door dezelfde persoon te laten noteren in 